\title{
Thermal Decomposition and Kinetics of Pentlandite-Bearing Ore Oxidation in the Air Atmosphere
}

\author{
Kristina Božinović ${ }^{1}$, Nada Štrbac ${ }^{1}$, Aleksandra Mitovski ${ }^{1, *}$,, Miroslav Sokić ${ }^{2}$, Duško Minić ${ }^{3}$, \\ Branislav Marković $^{2}$ (D) and Jovica Stojanović ${ }^{2}$ \\ 1 Technical Faculty in Bor, University of Belgrade, 19210 Bor, Serbia; kbozinovic@tfbor.bg.ac.rs (K.B.); \\ nstrbac@tf.bor.ac.rs (N.Š.) \\ 2 Institute for Technology of Nuclear and Other Mineral Raw Materials, 11000 Belgrade, Serbia; \\ m.sokic@itnms.ac.rs (M.S.); b.markovic@itnms.ac.rs (B.M.); j.stojanovic@itnms.ac.rs (J.S.) \\ 3 Faculty of Technical Science, University in Priština, 40000 Kosovska Mitrovica, Serbia; dusko.minic@pr.ac.rs \\ * Correspondence: amitovski@tfbor.bg.ac.rs
}

Citation: Božinović, K.; Štrbac, N.; Mitovski, A.; Sokić, M.; Minić, D.; Marković, B.; Stojanović, J. Thermal Decomposition and Kinetics of Pentlandite-Bearing Ore Oxidation in the Air Atmosphere. Metals 2021, 11, 1364. https://doi.org/10.3390/ met11091364

Academic Editor: Lai-Chang Zhang

Received: 8 July 2021

Accepted: 24 August 2021

Published: 30 August 2021

Publisher's Note: MDPI stays neutra with regard to jurisdictional claims in published maps and institutional affiliations.

Copyright: (c) 2021 by the authors. Licensee MDPI, Basel, Switzerland. This article is an open access article distributed under the terms and conditions of the Creative Commons Attribution (CC BY) license (https:// creativecommons.org/licenses/by/ $4.0 /)$.

\begin{abstract}
The roasting of sulfide ores and concentrates is one of the most important steps in pyrometallurgical metal production from primary raw materials, due to the necessity of excess sulfur removal, present in the virgin material. Pentlandite is one of the main sources for nickel pyrometallurgical production. The knowledge of its reaction mechanism, products distribution during oxidation and reaction kinetics is important for optimizing the production process. Raw pentlandite-bearing ore from the Levack mine (Ontario, Canada) was subjected to oxidative roasting in the air atmosphere. A chemical analysis of the initial sample was conducted according to EDXRF (Energy-Dispersive X-ray Fluorescence) and AAS (Atomic Adsorption Spectrometry) results. The characterization of the initial sample and oxidation products was conducted by an XRD (X-ray Diffraction) and SEM/EDS (Scanning Electron Microscopy with Energy Dispersive Spectrometry) analysis. Thermodynamic calculations, a phase analysis and construction of Kellogg diagrams for Ni-S-O and Fe-S-O systems at $298 \mathrm{~K}, 773 \mathrm{~K}, 923 \mathrm{~K}$ and $1073 \mathrm{~K}$ were used for proposing the theoretical reaction mechanism. A thermal analysis (TG/DTA-Thermogravimetric and Differential Thermal Analyses) was conducted in temperature range $298-1273 \mathrm{~K}$, under a heating rate of $15^{\circ} \mathrm{min}^{-1}$. A kinetic analysis was conducted according to the non-isothermal method of Daniels and Borchardt, under a heating rate of $15^{\circ} \mathrm{min}^{-1}$. Calculated activation energies of $113 \mathrm{~kJ} \mathrm{~mol}^{-1}, 146 \mathrm{~kJ} \mathrm{~mol}^{-1}$ and $356 \mathrm{~kJ} \mathrm{~mol}^{-1}$ for three oxidation stages imply that in every examined stage of the oxidation process, temperature is a dominant factor determining the reaction rate.
\end{abstract}

Keywords: pentlandite; oxidation; reaction mechanism; phase analysis

\section{Introduction}

Nickel has a long history of being used for coin manufacturing. Interest in nickel production from its ores, concentrates and secondary resources increased rapidly in recent decades with the expansion of its commercial use in new products. Nickel resistance to high temperatures, heat and good corrosion stability, allows its application in durable materials without replacement for a long time. Nickel is used in materials and alloys which can resist aggressive environments such as jet engines, offshore installations and power generation plants. Nickel is also applied as an alloying element in cast irons, austenitic stainless steels and non-ferrous alloys. Nickel steel is widely used for armor plating. Other nickel alloys are used in boat propeller shafts and turbine blades. Nickel is also used in batteries, including rechargeable nickel-cadmium batteries and nickel-metal hydride batteries used in hybrid vehicles. It is expected to form an ever-larger proportion of future batteries [1-7]; namely, pentlandite, complex nickel sulfide, may also be used as is, in the electrochemical reaction of hydrogen evolution [8-10]. 
Nickel can be extracted from its ores by both hydrometallurgical and pyrometallurgical routes. Almost $70 \%$ of ore deposits are processed by hydrometallurgical extraction. Although this route is more convenient, pyrometallurgical processing of nickel, as well as copper [11,12], from its sulfide ores is commonly used worldwide. It is known that nearly all of nickel in its sulfide ores occurs in the form of binary sulfide mineral pentlandite $\left((\mathrm{Ni}, \mathrm{Fe})_{9} \mathrm{~S}_{8}\right)$. Pentlandite is the most common and abundant mineral used for nickel extraction, accounting for over $60 \%$ of worldwide nickel production, mostly from sulfide copper-nickel ore deposits [13-15]. Pentlandite is usually associated with iron sulfides-pyrite $\left(\mathrm{FeS}_{2}\right)$ and pyrhotite $\left(\mathrm{Fe}_{7} \mathrm{~S}_{8}\right)$ and copper-iron sulfide chalcopyrite $\left(\mathrm{CuFeS}_{2}\right)$. Nickel sulfides are intergrown within the iron sulfides, with nickel dissolved in the crystal lattice. In metallurgical practice, this can cause technical difficulties in nickel concentrate production [16].

In the pyrometallurgical production of nickel from its sulfide ores and concentrates, one of the most important processing steps is controlling the iron sulfide oxidation process. Reactions which occur during the nickel sulfides oxidation have a highly exothermal character. The amount of sulfur removed during roasting is the main parameter for controlling the matte grade in the following smelting stage. Thus, the partial roasting of nickel sulfide ores and concentrates, in order to decrease the sulfur amount in nickel calcine, has been practiced for a few decades. Sulfur removal is conducted by roasting in fluidized bed reactors, in multiple hearth roasters or by smelting in a flash smelting furnace. Strong off-gases are generated and are suitable for $\mathrm{SO}_{2}$ capture and fixation. Certain changes were recently introduced into the process, which indicate to the most possible method of iron sulfide removal already in the ore milling stage [17].

The mechanism of sulfide minerals oxidation in the air atmosphere at elevated temperatures is quite complex, since it depends on sulfide species present in minerals, roasting conditions and the interactions between solid and gaseous phases in the investigated Me-S-O systems. A thermogravimetric (TG) and differential thermal analysis (DTA) under laboratory conditions, although having much milder oxidation conditions than the industrial roasting process, provides useful information on the reaction mechanism and kinetics of gas-solid reactions, for the possibility of a more precise control of experimental conditions and monitoring variable experimental parameters.

A literature review on reaction mechanisms of complex sulfide oxidation processes refers to two main possible processes: (1) forming a protective oxide layer on the particle surface, which inhibits the diffusion of reactive gas to unreacted inner core, and (2) predominant diffusion of one cation species in binary sulfides towards an oxygen rich interface, which leads to its preferential oxidation. Older reports on the oxidation of pentlandite, primarily involved heating it in an inert atmosphere [18-20].

Mkhonto et al. [21] in an ab initio study of oxygen adsorption on a nickel-rich pentlandite mineral surface confirmed that iron atoms are more reactive than nickel atoms, which implies preferential iron oxidation. Thornhill and Pidgeon [22] reported forming dense outer oxide shells below $923 \mathrm{~K}$, during pentlandite particles roasting. They also confirmed selective oxidation when roasting chalcopyrite and pentlandite, with a preferential oxidation of iron species in both particles and the increase in the copper content in chalcopyrite and nickel content in pentlandite. This is confirmed by the findings of Ellingham [23], whose diagrams show that change in Gibbs free energy values for iron oxides are lower in comparison to nickel oxide, while the trend is opposite in the case of sulfides. Ashcroft [24] assumed that iron acts such as a catalyzer in the formation of copper, zinc and nickel sulfates during the treatment of copper and nickel ores and concentrates. Tanabe et al. [25] determined that the outer and inner layers during the oxidation of dense pentlandite in a mixed $\mathrm{O}_{2}-\mathrm{N}_{2}$ atmosphere consisted of duplex oxide layers of $\mathrm{Fe}_{2} \mathrm{O}_{3}$ and $\mathrm{Fe}_{3} \mathrm{O}_{4}$, with the rapid increase in the $\mathrm{Fe}_{3} \mathrm{O}_{4}$ layer at the initial period of oxidation. Consequently, there can be observed the iron depletion in the unreacted sulfide core in a pentlandite sample heated in air to $923 \mathrm{~K}$. The oxidation behavior of pyrrhotite in air and oxygen was investigated by Kennedy and Sturman [26]. Dunn and Kelly [27] reported the 
oxidation of synthetic millerite prior to the investigation of natural mineral pentlandite oxidation at elevated temperatures in a dynamic oxygen atmosphere [28]. Results showed that in temperature interval 733-973 K, pentlandite decomposed into $\mathrm{Fe}_{2} \mathrm{O}_{3}, \mathrm{NiSO}_{4}, \mathrm{NiO}$, $\mathrm{NiS}$ and $\mathrm{NiFe}_{2} \mathrm{O}_{4}$. Iron sulfate decomposed above $913 \mathrm{~K}$. Above $1073 \mathrm{~K}$, only oxides $\mathrm{NiO}$ and $\mathrm{Fe}_{2} \mathrm{O}_{3}$ and spinel-phase trevorite $\mathrm{NiFe}_{2} \mathrm{O}_{4}$ were detected. Zhu et al. [29] reported the existence of nickel and sulfur-rich phases as intermediate phases in unreacted cores during the oxidation of synthetic pentlandite at $973 \mathrm{~K}$ in isothermal conditions. Hematite, trevorite and nickel oxide were observed as the final oxidation products. An SEM/EDS analysis showed the formation of gaps and holes between the oxide shell and sulfide core. Reaction rate was rapid in the first two hours, then it slowed down. Xia et al. [14] also investigated a sintetic pentlandite oxidation behavior at the temperature range of 530-600 ${ }^{\circ} \mathrm{C}$ by microscopic and kinetic methods. The proposed reaction mechanism involved the transformation of pentlandite to a monosulfide solid solution (mss), (Fe, Ni)S, following to $\alpha$-NiS in the second step, oxidation from $\mathrm{Fe}_{3} \mathrm{O}_{4}$ to $\mathrm{Fe}_{2} \mathrm{O}_{3}$ in the third step, and the oxidation of $\alpha-\mathrm{NiS}$ to $\mathrm{NiO}$ as the final step. Corresponding activation energies $\left(140 \mathrm{~kJ} \mathrm{~mol}^{-1}, 151\right.$ $\mathrm{kJ} \mathrm{mol}^{-1}$ and $127 \mathrm{~kJ} \mathrm{~mol}^{-1}$ ) were calculated according to the Avrami/Arrhenius analysis. A thermogravimetric analysis of oxidation of a floated nickel sulfide concentrate mixture in an oxygen and air atmosphere, under various heating rates, was performed by Dunn and Jayaweera [30]. Two mass gains were observed, which correspond to metal sulfates formation. The thermoanalytical results showed a significant dependence on the heating rate. The air atmosphere reactions occur to a lesser extent comparing to the results of oxidation in the oxygen atmosphere. Pandher and Utigard [31] studied roasting of three nickel concentrates, consisting of pentlandite, pyrrhotite, silica and chalcopyrite by TGA analysis in an inert or oxidizing atmosphere in order to determine the reaction mechanism. Two broad peaks on the TG curve were observed, instead of one gradual bell-shaped peak while heating the nickel concentrates in inert atmospheres. According to mass changes, it was assumed that sulfates form in a temperature range from $773 \mathrm{~K}$ to $973 \mathrm{~K}$. Yu and Utigard [32] reported TG/DTA results on the oxidation of nickel concentrate from an ambient temperature up to $1273 \mathrm{~K}$. A reaction mechanism was proposed, where the preferential oxidation of iron sulfide occurred between $623 \mathrm{~K}$ and $973 \mathrm{~K}$. At $1086 \mathrm{~K}$, a nickel sulfide core melted and decomposed, forming $\mathrm{NiO}$ and $\mathrm{NiSO}_{4}$. At $1215 \mathrm{~K}$ sulfate decomposed and all remaining nickel sulfide transformed into oxide due to the absence of a protective sulfate layer. Results of a kinetic analysis indicate that the diffusion of oxygen controls the reaction rate. Although some of the results agreed on some level with Dunn and Kelly [28], some discrepancies can be noticed regarding oxidation products and following the mechanism of pentlandite oxidation.

In recent years, pentlandite has been broadly researched due to its newly discovered usage. On the other hand, the mechanism of the pentlandite oxidation process itself has not been fully understood, considering the complexity of natural sulfide minerals. Nearly all of nickel in its sulfide ores occurs in the form of pentlandite. As a contribution to a better understanding of the pentlandite-bearing ore oxidation process in the air atmosphere at elevated temperatures, the results of characterization, thermodynamic, thermal and kinetic analysis are presented in this paper.

\section{Materials and Methods}

Pentlandite-bearing ore, from the Levack mine (Ontario, Canada) was used for the experimental investigation. Initial samples were prepared by crushing and milling a solid piece of pentlandite-bearing ore and then used in powder form. Sampling was performed by standard procedure of bulk mineral sampling division, first by quartering and then by chess field method, in order to ensure a homogeneous distribution and representative portion of all present mineral fractions in the initial sample.

Qualitative chemical analysis of the initial sample was conducted according to EDXRF (Energy-Dispersive X-ray Fluorescence) analysis, on an analyzer (Canberra Packard, Schwadorf, Austria) with radioisotopes for Cd-109 excitation (22.1 keV). The weight of the sample was 
$0.5 \mathrm{~g}$. Quantitative chemical analysis was carried out using atomic adsorption spectrometry (AAS) (AAS PinAAcle 900 T, PerkinElmer, Überlingen, Germany). Examined samples (in three replicates) were previously dissolved by the nitric-perchloric acid digestion method described by Hseu [33], and the contents of selected inorganics were determined from the solution. A part of Si that remained undissolved in the form of a precipitate was further determined by the hydrochloric acid dehydration (gravimetric) technique [34].

Characterization of the initial sample and the oxidation products was conducted by X-ray diffraction method on X-ray diffractometer, model PW-1710 (PHILIPS, Eindhoven, The Netherlands), with a curved graphite monochromator and a scintillation counter. The intensities of diffracted $\mathrm{CuK} \alpha \mathrm{X}$-rays $(\lambda=1.54178 \AA)$ were measured at room temperature at intervals of $0.02{ }^{\circ} 2 \theta$ and a time of $1 \mathrm{~s}$ in the range from 4 to $65^{\circ} 2 \theta$. The $X$-ray tube was loaded with a voltage of $40 \mathrm{kV}$ and a current of $30 \mathrm{~mA}$, while the slots for directing the primary and diffracted beam were $1^{\circ}$ and $0.1 \mathrm{~mm}$. The samples investigated by XRD method were isothermally roasted for $30 \mathrm{~min}$ in previously preheated furnace in the air atmosphere at $673 \mathrm{~K}, 773 \mathrm{~K}, 873 \mathrm{~K}, 973 \mathrm{~K}$ and $1073 \mathrm{~K}$. Oxidation products were taken out of the furnace and cooled in the air atmosphere at room temperature.

The initial sample and the oxidation products were analyzed by scanning electron microscope with energy dispersive spectrometry (SEM/EDS) using a VEGA3 Scanning Electron Microscope (TESCAN, Brno, Czech Republic). In order to better understand the reaction mechanism of the oxidation process of the pentlandite-bearing ore, a thermal analysis of the sample was also performed. TG/DTA analysis was performed with a single heating rate of $15^{\circ} \mathrm{min}^{-1}$, in temperature range 298-1273 K, using a STA $409 \mathrm{EP}$ (Netzsch, Selb, Germany). Thermal analysis and X-ray diffraction experiments were performed on $100 \mathrm{mg}$ initial samples.

Proposing theoretical reaction mechanism included thermodynamic calculation, phase analysis and construction of Kellogg's diagrams for Ni-S-O and Fe-S-O systems at various temperatures: 298 K, 773 K, $923 \mathrm{~K}$ and 1073 K. Based on the constructed Kellogg's diagrams, with values of the oxygen partial pressures which correspond to industrial conditions, the possible reaction paths in these two systems at $773 \mathrm{~K}, 923 \mathrm{~K}$ and $1073 \mathrm{~K}$ were proposed. Thermodynamically possible reactions in the Ni-S-O and Fe-S-O systems were proposed and the changes in Gibbs free energy at $298 \mathrm{~K}, 773 \mathrm{~K}, 923 \mathrm{~K}$ and $1073 \mathrm{~K}$ were calculated.

Kinetic analysis of pentlandite oxidation process in the air atmosphere was conducted using non-isothermal method of Daniels and Borchardt [35,36], at heating rate of $15^{\circ} \mathrm{min}^{-1}$.

\section{Results and Discussion}

\subsection{Results of Chemical Analysis}

A qualitative chemical analysis of the examined sample was performed by EDXRF analysis and the presence of the following elements was detected in the sample: iron, nickel, copper, sulfur, as well as other accompanying components of tailings.

The content (quantitative analysis) of the elements that EDXRF indicated and which were the subject of our research was determined by the AAS method and is shown in Table 1.

Table 1. Chemical composition of the initial pentlandite sample.

\begin{tabular}{ccccccccc}
\hline Element & Fe & S & Ni & Si & Cu & Ca & Mn & Pb \\
\hline Mass \% & 41.63 & 25.90 & 5.12 & 4.8 & 0.4 & 2.74 & 0.034 & 0.016 \\
\hline
\end{tabular}

\subsection{X-ray Diffraction Results}

The characterization of the initial pentlandite sample at $298 \mathrm{~K}$ and oxidation products at $673 \mathrm{~K}, 773 \mathrm{~K}, 873 \mathrm{~K}, 973 \mathrm{~K}$ and $1073 \mathrm{~K}$ was conducted by an X-ray diffraction method on a polycrystalline powder sample. The results of the X-ray analysis of the initial sample and oxidation products at different temperatures are given in Figure 1. In the initial ore sample, at room temperature, the following sulfide minerals were observed: pyrrhotite (FeS), pentlandite $\left((\mathrm{Fe}, \mathrm{Ni})_{9} \mathrm{~S}_{8}\right)$, pyrite $\left(\mathrm{FeS}_{2}\right)$, magnetite $\left(\mathrm{Fe}_{3} \mathrm{O}_{4}\right)$, chalcopyrite $\left(\mathrm{CuFeS}_{2}\right)$, gangue 
minerals quartz $\left(\mathrm{SiO}_{2}\right)$ and feldspar $\left((\mathrm{K}, \mathrm{Na}) \mathrm{Si}_{3} \mathrm{O}_{8}\right)$. The most abundant were pyrrhotite and pentlandite, to a lesser extent pyrite and magnetite, while quartz, feldspar and chalcopyrite were significantly less prevalent. According to Figure 1, the decomposition of pentlandite began below $673 \mathrm{~K}$, which was why there was NiS present at $673 \mathrm{~K}$. The intensification of the pentlandite oxidation process occurs below $873 \mathrm{~K}$, that is why the characterization of the oxidation products at $873 \mathrm{~K}$ showed no pentlandite. It can be observed that NiS was present even at $1073 \mathrm{~K}$. Since copper minerals were significantly less present, chalcopyrite oxidation products were not shown on the XRD diffractograms of oxidation products at higher temperatures.

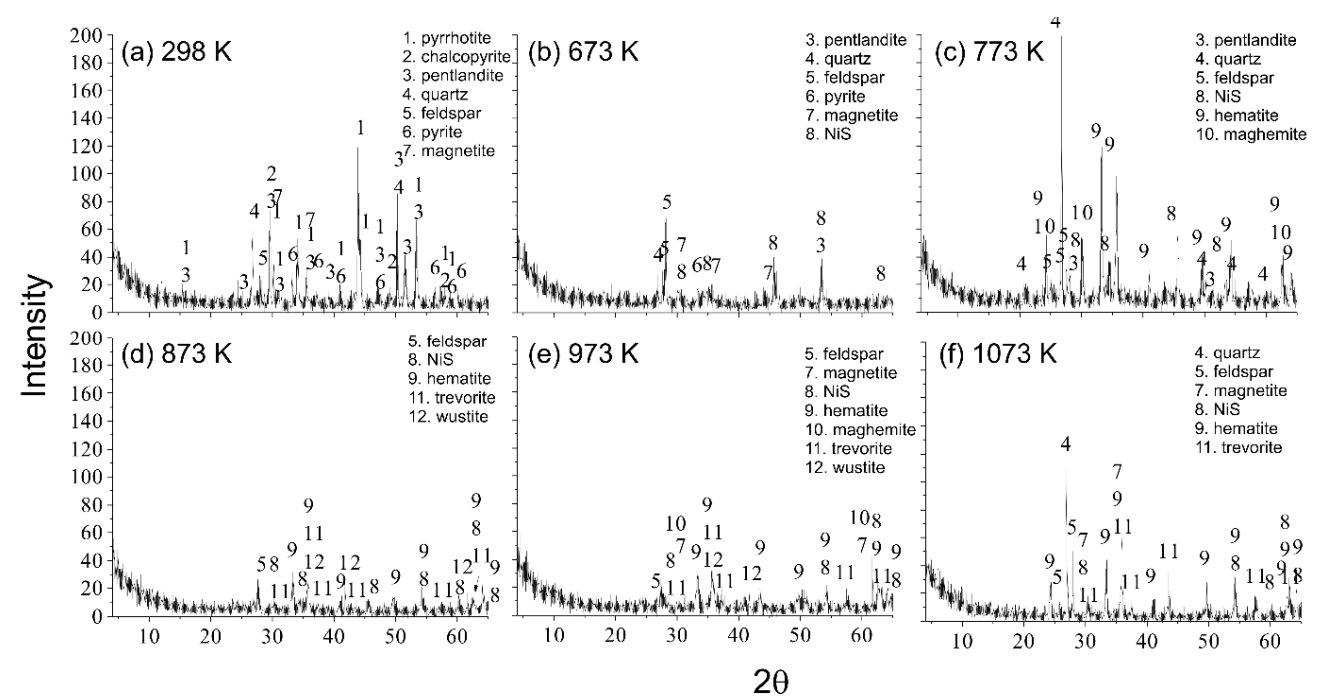

Figure 1. The results of XRD analysis for the (a) initial sample, (b) oxidation product at $673 \mathrm{~K},(\mathbf{c}) 773$ K, (d) $873 \mathrm{~K}$, (e) $973 \mathrm{~K}$ and (f) $1073 \mathrm{~K}$.

\subsection{SEM/EDS Analysis}

The SEM/EDS analysis was performed on the initial sample and on solid residues after 30 min roasting at $673 \mathrm{~K}, 773 \mathrm{~K}, 873 \mathrm{~K}, 973 \mathrm{~K}$ and $1073 \mathrm{~K}$, in order to compare the obtained results with the results of the XRD analysis. The SEM microphotographs are given in Figure 2, while marked areas were used for the EDS analysis. Based on the EDS analysis results (atomic percentages of elements on the sample surface), phase compositions of the initial sample and the oxidation products were calculated and given in Table 2.

The SEM/EDS analysis showed that nickel-bearing sulfides were intergrown with quartz or gangue minerals at lower temperatures. With the temperature increase, to above $873 \mathrm{~K}$, still present NiS was found incorporated within the iron oxides hematite and wustite. The occurrence of the spinel phase trevorite $\left(\mathrm{NiFe}_{2} \mathrm{O}_{4}\right)$ was also observed at higher temperatures.

\subsection{The Results of Thermodynamic Analysis}

The determination of thermodynamically stable phases in the Me-S-O system $(\mathrm{Me}=\mathrm{Ni}$, $\mathrm{Fe}$ ) required a construction of Kellogg's (PAD = Predominance Area Diagrams) (Figures 3 and 4) diagrams, as a function:

$$
\begin{gathered}
\log \mathrm{pSO}_{2(\mathrm{~g})}=\mathrm{f}\left(\log \mathrm{pO}_{2(\mathrm{~g})}\right) \\
\log \mathrm{pO}_{2(\mathrm{~g})}=\mathrm{f}(\mathrm{T})
\end{gathered}
$$




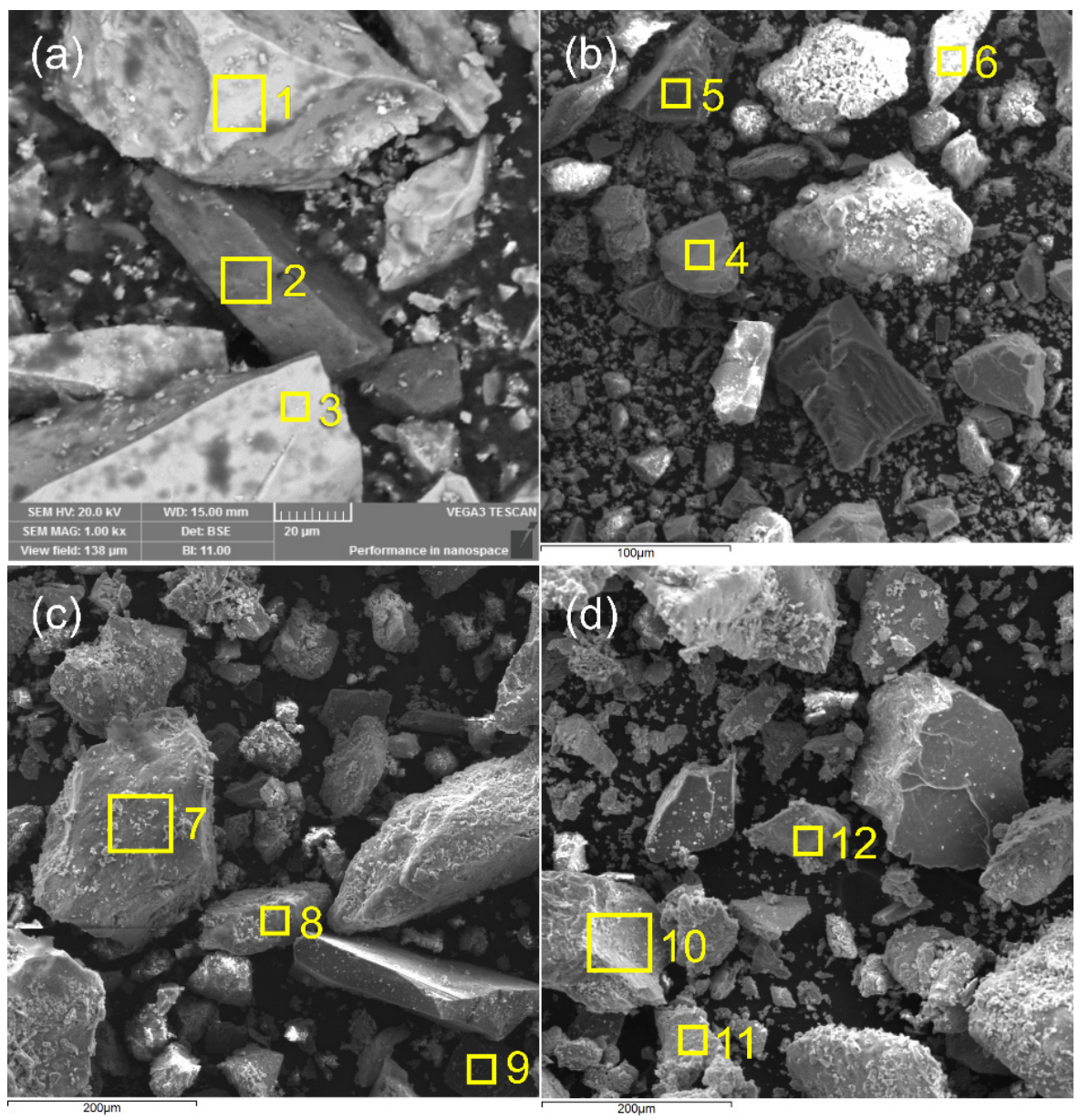

Figure 2. Microphotographs with EDS analysis of the pentlandite-bearing ore (a) $298 \mathrm{~K}$ and the initial sample roasted at (b) $773 \mathrm{~K}$, (c) $873 \mathrm{~K}$ and (d) $1073 \mathrm{~K}$.

Table 2. Phase composition of the initial sample and the oxidation products according to EDS analysis.

\begin{tabular}{|c|c|c|}
\hline Temperature $\mathrm{K}$ & Spectrum & Species \\
\hline \multirow{3}{*}{298} & 1 & quartz $\left(\mathrm{SiO}_{2}\right)$ \\
\hline & 2 & pentlandite $\left((\mathrm{Fe}, \mathrm{Ni})_{9} \mathrm{~S}_{8}\right)$ \\
\hline & 3 & pyrite $\left(\mathrm{FeS}_{2}\right)$ \\
\hline \multirow{3}{*}{773} & 4 & $\mathrm{NiS}+$ hematite $\left(\mathrm{Fe}_{2} \mathrm{O}_{3}\right)$ \\
\hline & 5 & $\begin{array}{c}\text { pentlandite }\left((\mathrm{Fe}, \mathrm{Ni})_{9} \mathrm{~S}_{8}\right)+ \\
\text { quartz }\left(\mathrm{SiO}_{2}\right)\end{array}$ \\
\hline & 6 & $\begin{array}{c}\text { pentlandite }\left((\mathrm{Fe}, \mathrm{Ni})_{9} \mathrm{~S}_{8}\right)+ \\
\text { gangue minerals }\end{array}$ \\
\hline \multirow{3}{*}{873} & 7 & $\mathrm{NiS}+$ hematite $\left(\mathrm{Fe}_{2} \mathrm{O}_{3}\right)$ \\
\hline & 8 & $\begin{array}{c}\mathrm{NiS}+\text { wustite }(\mathrm{FeO})+\text { quartz } \\
\left(\mathrm{SiO}_{2}\right)\end{array}$ \\
\hline & 9 & trevorite $\left(\mathrm{NiFe}_{2} \mathrm{O}_{4}\right)$ \\
\hline \multirow{3}{*}{1073} & 10 & $\begin{array}{c}\mathrm{NiS}+\text { hematite }\left(\mathrm{Fe}_{2} \mathrm{O}_{3}\right)+ \\
\text { gangue minerals }\end{array}$ \\
\hline & 11 & $\begin{array}{l}\text { trevorite }\left(\mathrm{NiFe}_{2} \mathrm{O}_{4}\right)+\text { hematite } \\
\qquad\left(\mathrm{Fe}_{2} \mathrm{O}_{3}\right)\end{array}$ \\
\hline & 12 & $\begin{array}{l}\text { magnetite }\left(\mathrm{Fe}_{3} \mathrm{O}_{4}\right)+\text { trevorite } \\
\qquad\left(\mathrm{NiFe}_{2} \mathrm{O}_{4}\right)\end{array}$ \\
\hline
\end{tabular}



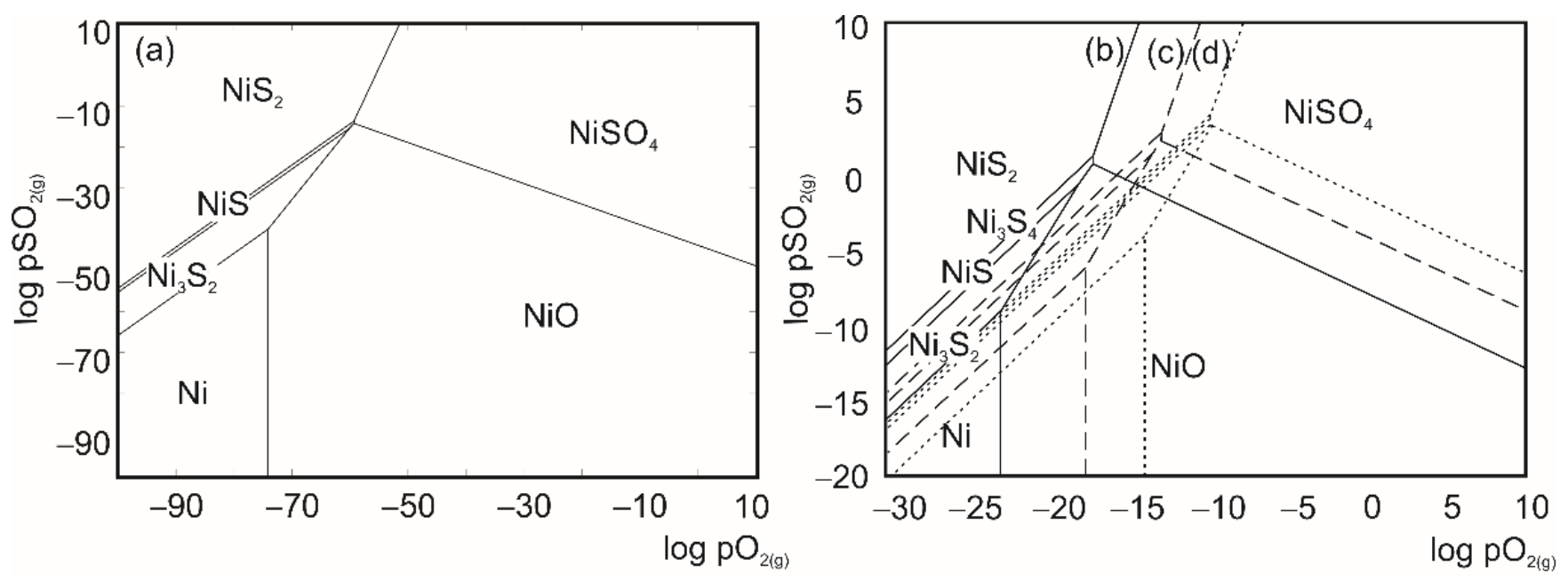

Figure 3. Kellogg diagrams constructed for Ni-S-O system at (a) 298 K, (b) 773 K, (c) 923 K and (d) 1073 K [37,38].
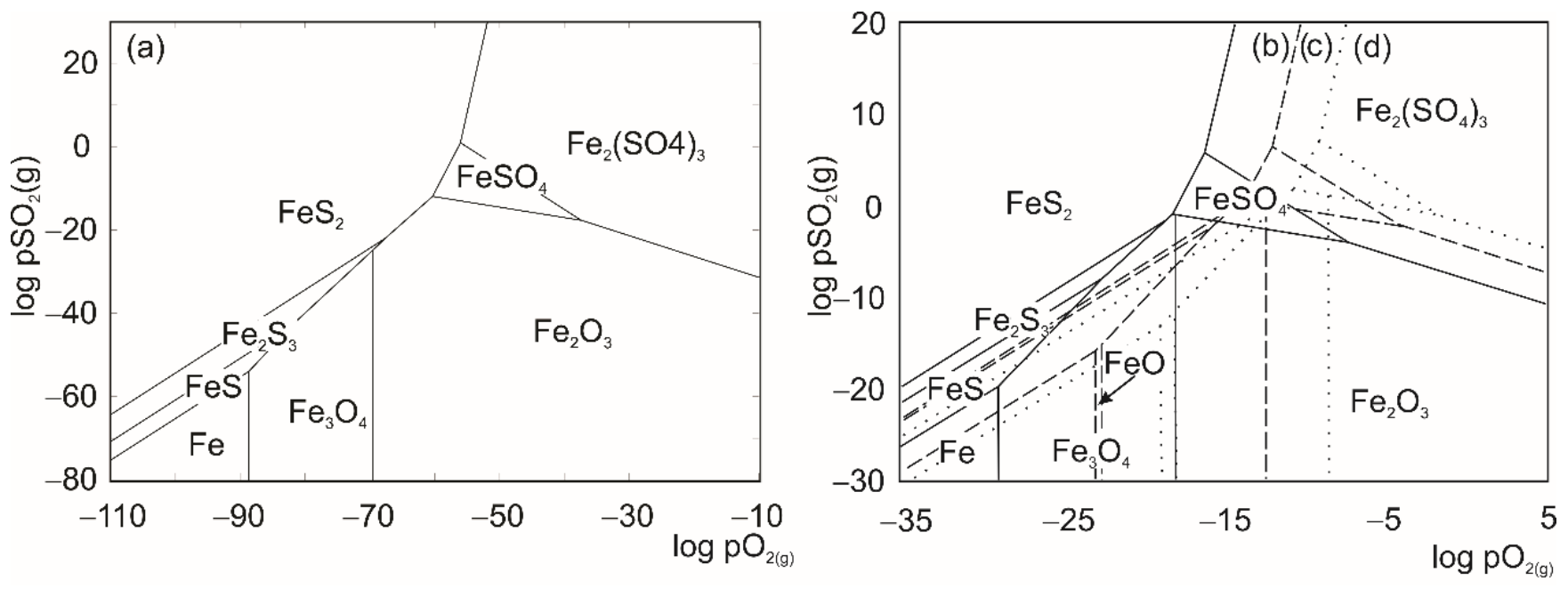

Figure 4. Kellogg diagrams constructed for Fe-S-O system at (a) 298 K, (b) 773 K, (c) 923 K and (d) 1073 K [37,38].

For the Kellogg diagrams construction solid phases such as oxides, sulfates, sulfides and metals, they were taken in consideration and diagrams were constructed in four characteristic temperatures ( $298 \mathrm{~K}, 773 \mathrm{~K}, 923 \mathrm{~K}$, and $1073 \mathrm{~K})$. Partial pressures in the HSC Chemistry software (9.0, Outotec) for PAD construction were given in bar units [36].

Regarding the constructed diagrams, the theoretically proposed reaction paths for Ni-S-O and Fe-S-O systems are presented in Table 3.

The theoretically obtained reaction paths were proposed for constant values of $\mathrm{SO}_{2}$ partial pressure $\left(10^{-4}\right.$ bar and 1 bar $)$, which correspond to industrial partial pressures of $\mathrm{SO}_{2}$ gas [38]. Observing the constructed PAD diagrams, the regarded partial pressures marked off an area within which the theoretical mechanism of oxidative roasting was defined. It can be observed that for every investigated temperature and corresponding pressure based on the theoretical mechanism, in the Ni-S-O system, the final stable phase was always $\mathrm{NiSO}_{4}$ and there could not be a direct sulfide transformation to oxide. In the Fe-S-O system, the final theoretical stable phase was always $\mathrm{Fe}_{2}\left(\mathrm{SO}_{4}\right)_{3}$. 
Table 3. Theoretically proposed reaction paths for oxidation process in the Ni-S-O and Fe-S-O systems.

\begin{tabular}{|c|c|}
\hline System & Theoretical Reaction Path \\
\hline $\mathrm{Ni}-\mathrm{S}-\mathrm{O}$ & 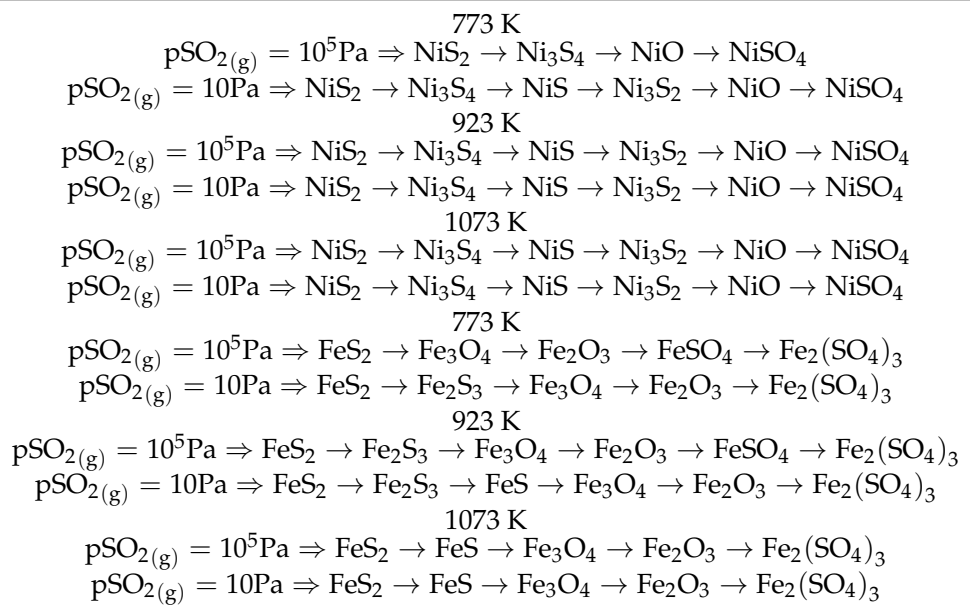 \\
\hline
\end{tabular}

In addition, the Tpp Predominance Area Diagrams (temperature-partial pressure diagrams) were calculated for both systems as a function:

$$
\mathrm{pSO}_{2(\mathrm{~g})}=\mathrm{f}(\mathrm{T})
$$

with a partial pressure of oxygen 0.1 bar. Calculated diagrams (Figure 5) imply that during an oxidation process, $\mathrm{Ni}$ and Fe sulfates were expected to form even at lower temperatures.
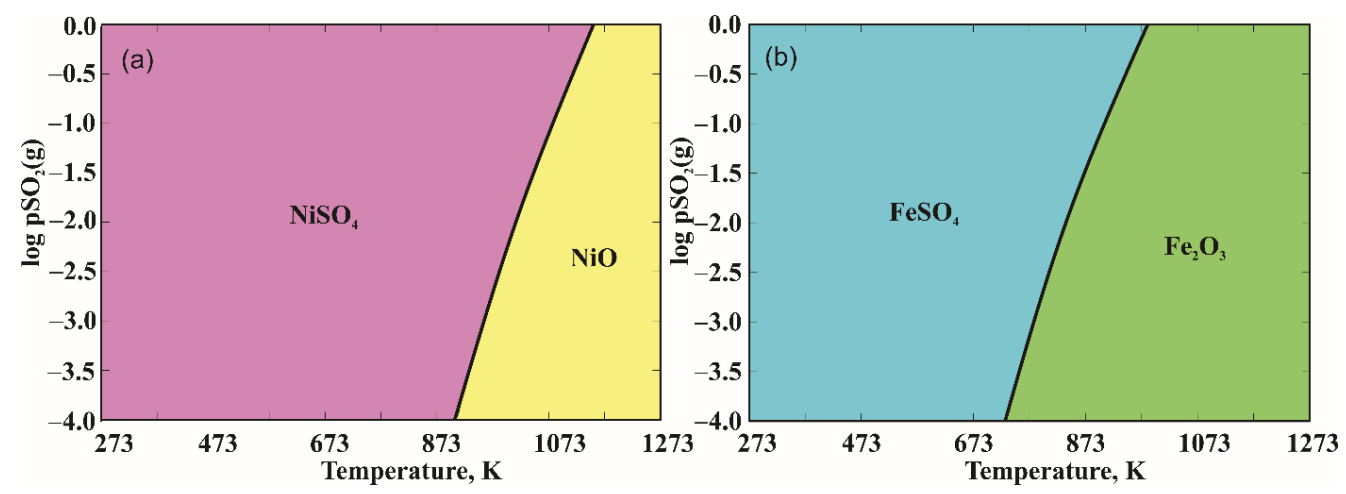

Figure 5. Tpp Predominance Area Diagrams for (a) Ni-S-O and (b) Fe-S-O system for a constant value of oxygen partial pressure [37].

Based on the theoretical calculations, reactions in the given systems were proposed and changes in Gibbs free energy were calculated. Thermodynamically possible reactions for both systems are given in Table 4 . 
Table 4. Values of change in Gibbs free energy calculated for theoretically proposed reactions for Ni-S-O and Fe-S-O systems [37].

\begin{tabular}{|c|c|c|c|}
\hline \multirow{2}{*}{ Reaction } & \multicolumn{3}{|c|}{ 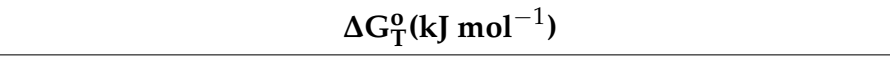 } \\
\hline & $773 \mathrm{~K}$ & $923 \mathrm{~K}$ & $1073 \mathrm{~K}$ \\
\hline $3 \mathrm{NiS}_{2}+2 \mathrm{O}_{2(\mathrm{~g})}=\mathrm{Ni}_{3} \mathrm{~S}_{4}+2 \mathrm{SO}_{2}(\mathrm{~g})$ & -543 & -552 & -562 \\
\hline $\mathrm{Ni}_{3} \mathrm{~S}_{4}+5.5 \mathrm{O}_{2(\mathrm{~g})}=3 \mathrm{NiO}+4 \mathrm{SO}_{2}(\mathrm{~g})$ & -1439 & -1404 & -1368 \\
\hline $\mathrm{Ni}_{3} \mathrm{~S}_{4}+\mathrm{O}_{2(\mathrm{~g})}=3 \mathrm{NiS}+\mathrm{SO}_{2(\mathrm{~g})}$ & -270 & -273 & -275 \\
\hline $3 \mathrm{NiS}+\mathrm{O}_{2}(\mathrm{~g})=\mathrm{Ni}_{3} \mathrm{~S}_{2}+\mathrm{SO}_{2}(\mathrm{~g})$ & -257 & -261 & -269 \\
\hline $\mathrm{Ni}_{3} \mathrm{~S}_{2}+3.5 \mathrm{O}_{2}(\mathrm{~g})=3 \mathrm{NiO}+2 \mathrm{SO}_{2}(\mathrm{~g})$ & -912 & -870 & -824 \\
\hline $2 \mathrm{NiO}+2 \mathrm{SO}_{2(\mathrm{~g})}+\mathrm{O}_{2(\mathrm{~g})}=2 \mathrm{NiSO}_{4}$ & -231 & -148 & -66 \\
\hline $3 \mathrm{FeS}_{2}+8 \mathrm{O}_{2(\mathrm{~g})}=\mathrm{Fe}_{3} \mathrm{O}_{4}+6 \mathrm{SO}_{2(\mathrm{~g})}$ & -2254 & -2232 & -2210 \\
\hline $2 \mathrm{FeS}_{2}+\mathrm{O}_{2(\mathrm{~g})}=\mathrm{Fe}_{2} \mathrm{~S}_{3}+\mathrm{SO}_{2}(\mathrm{~g})$ & -283 & -284 & -283 \\
\hline $\mathrm{FeS}_{2}+\mathrm{O}_{2(\mathrm{~g})}=\mathrm{FeS}+\mathrm{SO}_{2(\mathrm{~g})}$ & -271 & -281 & -291 \\
\hline $4 \mathrm{Fe}_{3} \mathrm{O}_{4}+\mathrm{O}_{2(\mathrm{~g})}=6 \mathrm{Fe}_{2} \mathrm{O}_{3}$ & -266 & -220 & -175 \\
\hline $1.5 \mathrm{Fe}_{2} \mathrm{~S}_{3}+6.5 \mathrm{O}_{2(\mathrm{~g})}=\mathrm{Fe}_{3} \mathrm{O}_{4}+4.5 \mathrm{SO}_{2(\mathrm{~g})}$ & -1829 & -1805 & -1786 \\
\hline $\mathrm{Fe}_{2} \mathrm{~S}_{3}+\mathrm{O}_{2}(\mathrm{~g})=2 \mathrm{FeS}+\mathrm{SO}_{2}(\mathrm{~g})$ & -259 & -278 & -299 \\
\hline $3 \mathrm{FeS}+5 \mathrm{O}_{2(\mathrm{~g})}=\mathrm{Fe}_{3} \mathrm{O}_{4}+3 \mathrm{SO}_{2(\mathrm{~g})}$ & -1440 & -1388 & -1337 \\
\hline $2 \mathrm{Fe}_{2} \mathrm{O}_{3}+4 \mathrm{SO}_{2(\mathrm{~g})}+\mathrm{O}_{2(\mathrm{~g})}=4 \mathrm{FeSO}_{4}$ & -201 & -72 & 55 \\
\hline $\mathrm{Fe}_{2} \mathrm{O}_{3}+3 \mathrm{SO}_{2(\mathrm{~g})}+1.5 \mathrm{O}_{2(\mathrm{~g})}=\mathrm{Fe}_{2}\left(\mathrm{SO}_{4}\right)_{3}$ & -230 & -108 & 14 \\
\hline $2 \mathrm{FeSO}_{4}+\mathrm{SO}_{2(\mathrm{~g})}+\mathrm{O}_{2(\mathrm{~g})}=\mathrm{Fe}_{2}\left(\mathrm{SO}_{4}\right)_{3}$ & -129 & -71 & -13 \\
\hline
\end{tabular}

\subsection{The Results of Thermal Analysis}

For the investigated ore sample, the thermogravimetric and differential thermal analyses were conducted in air atmosphere, with a heating rate of $15^{\circ} \mathrm{min}^{-1}$. The temperature range was $298-1273 \mathrm{~K}$. The comparative results of the TG/DTA analysis are given in Figure 6.

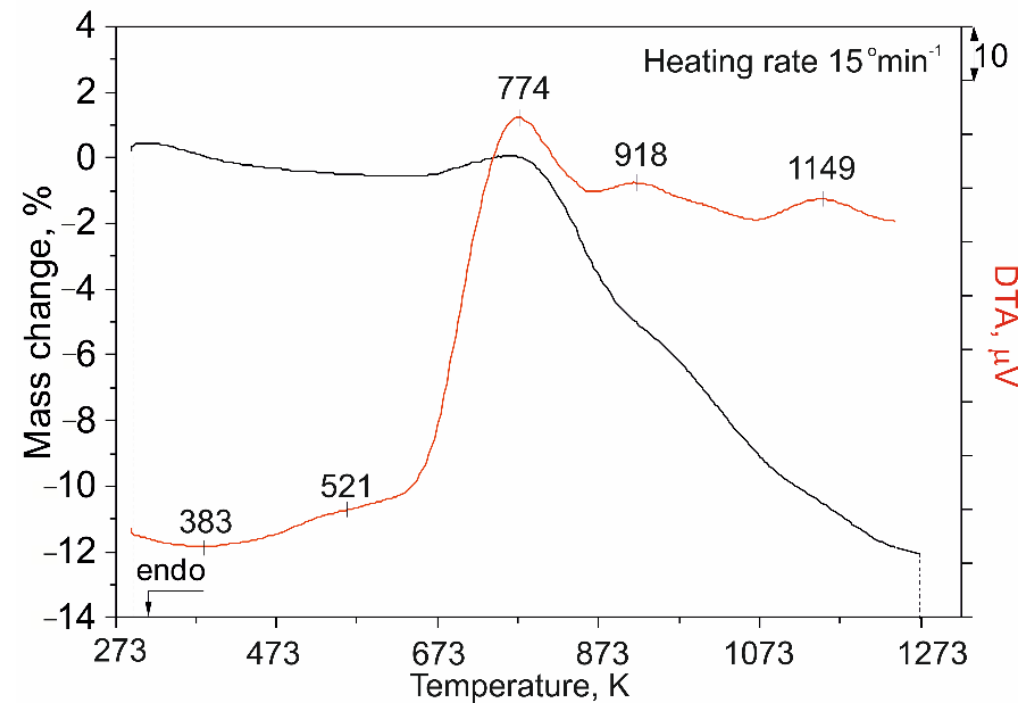

Figure 6. Comparative results of TG/DTA analysis for the investigated pentlandite-bearing ore sample.

Obtained TG/DTA heating curves were analyzed in comparison to the results of XRD and SEM/EDS analyses, as well as the calculated thermodynamically possible reaction paths (Table 3) and theoretically proposed reactions (Table 4). Based on the above, the actual oxidation mechanism was proposed. 
Heating the investigated ore sample at the temperature range of $473-573 \mathrm{~K}$ gave a slight exothermic peak on the DTA curve at $521 \mathrm{~K}$ and a small mass decrease on the TG curve, which correspond to the beginning of the pyrite oxidation, according to Equation (4):

$$
\mathrm{FeS}_{2}+\mathrm{O}_{2} \rightarrow \mathrm{FeS}+\mathrm{SO}_{2}
$$

Although it is expected that pyrite oxidation took place at higher temperatures [20], the formation of pyrrhotite from oxidation in the air atmosphere could occur at lower temperatures due to the easy oxidation of sulfur by oxygen to $\mathrm{SO}_{2}$ [39].

Based on the available literature [40], and the results of the XRD analysis, it was assumed that formed, and already existing, FeS was further oxidized up to $673 \mathrm{~K}$, according to Equation (5):

$$
3 \mathrm{FeS}+5 \mathrm{O}_{2} \rightarrow \mathrm{Fe}_{3} \mathrm{O}_{4}+3 \mathrm{SO}_{2}
$$

Over $773 \mathrm{~K}$, there can be noticed three different exothermic peaks on the DTA curve with appropriate changes of mass on the TG curve. Regarding the first DTA peak (774 K), the area beneath spread from $623 \mathrm{~K}$ up to almost $873 \mathrm{~K}$. In the beginning of the suggested temperature range, there can be seen a mass increase on the TG curve, until the first DTA peak, after which the mass of the investigated sample began sharply decreasing. It was assumed that these results suggested sulfate formation by Equation (6):

$$
2 \mathrm{Fe}_{2} \mathrm{O}_{3}+4 \mathrm{SO}_{2}+\mathrm{O}_{2} \rightarrow 4 \mathrm{FeSO}_{4}
$$

even though, because of their instability, they were not spotted according to the XRD analysis. The assumption was that prolonged roasting was a necessity in order to achieve thermodynamic equilibrium, for sulfate detection on the XRD diffractograms. The formation of sulfates would imply a mass increase, which was not the case for the whole investigated temperature range. A mass loss, which occurred on the TG curve, could be explained by the decomposition of pentlandite and an intense $\mathrm{SO}_{2}$ gas removal, which in this temperature range "masked" the sulfate formation. Based on the XRD analysis results, the presence of the high-temperature NiS phase could be detected even at $673 \mathrm{~K}$, pinpointing the decomposition of pentlandite. Based on the results of the XRD and EDS analyses, and prior investigations [20], the existence of pentlandite could be determined even at $773 \mathrm{~K}$. This implies that pentlandite decomposition took place in a wide temperature range giving an impoverished pentlandite [25], $\mathrm{FeS}_{2}$ and NiS. Further heating brought a second exothermic peak at $918 \mathrm{~K}$ on the DTA curve, with a corresponding mass loss on the TG curve. Based on the same research [20], and the obtained results, this peak could be explained as a sulfate decomposition, according to Equation (7):

$$
\mathrm{FeSO}_{4} \rightarrow \mathrm{FeO}+\mathrm{SO}_{2}+0.5 \mathrm{O}_{2}
$$

In this temperature interval, the decomposition of impoverished pentlandite led to the formation of $\mathrm{NiFe}_{2} \mathrm{O}_{4}$ spinel, trevorite [41,42], which was confirmed together with $\mathrm{Fe}_{2} \mathrm{O}_{3}$ in the results of the XRD analysis at $873 \mathrm{~K}$ [25], given by Equation (8):

$$
(\mathrm{Fe}, \mathrm{Ni})_{8 \pm x} \mathrm{~S}_{6 \pm \mathrm{y}}+\mathrm{O}_{2} \rightarrow \mathrm{NiFe}_{2} \mathrm{O}_{4}+\mathrm{Fe}_{2} \mathrm{O}_{3}+\mathrm{NiO}+\mathrm{SO}_{2}
$$

It was assumed that the reaction between the formed $\mathrm{NiO}$ and existing $\mathrm{Fe}_{2} \mathrm{O}_{3}$ took place, leading to the subsequent formation of Ni-Fe spinel. The mass loss on the TG curve, corresponding to this exothermic peak, was explained with $\mathrm{SO}_{2}$ emission. The higher temperature brought to another exothermic peak on the DTA curve with a corresponding mass loss on the TG curve. This change at $1149 \mathrm{~K}$ was assumed to be the oxidation of the high-temperature NiS phase, which was present even at $1073 \mathrm{~K}$, with a constant spinel formation and $\mathrm{SO}_{2}$ emission, explaining this mass loss.

Accessible literature data [27] and the theoretically proposed reaction mechanism suggest that NiS oxidation and sulfate formation occurred at temperature range of 733-988 
K. One of the possible reasons for the difficulty of sulfate detection in the oxidation products was the non-equilibrium conditions (roasting time of $30 \mathrm{~min}$ ) [20]. Another possible reason for the absence of sulfates could be explained with the preferential oxidation of iron, followed by the formation of protective coatings of the iron oxidation products on the mineral particle surface. This prevented oxygen diffusion to the reaction zone while allowing the existence of $\mathrm{NiS}$ in the inner core of the particle $[20,25,27,31]$.

\subsection{The Results of Kinetic Analysis}

The kinetic analysis of the pentlandite-bearing ore oxidation process was performed using the method of non-isothermal kinetics of Daniels and Borchardt under a constant heating rate. The heating of the sample was performed in an air atmosphere, in a temperature range of 298-1273 $\mathrm{K}$ under a heating rate of $15^{\circ} \mathrm{min}^{-1}$. Based on the results of the DTA analysis (Figure 6), three characteristic stages were defined. Three exothermal peaks ( $774 \mathrm{~K}, 918 \mathrm{~K}$ and $1149 \mathrm{~K}$ ) were used for the kinetic parameters calculation. Based on the given method, activation energies were calculated for the observed oxidation stages and the results are given in Figure 7 and Table 5.

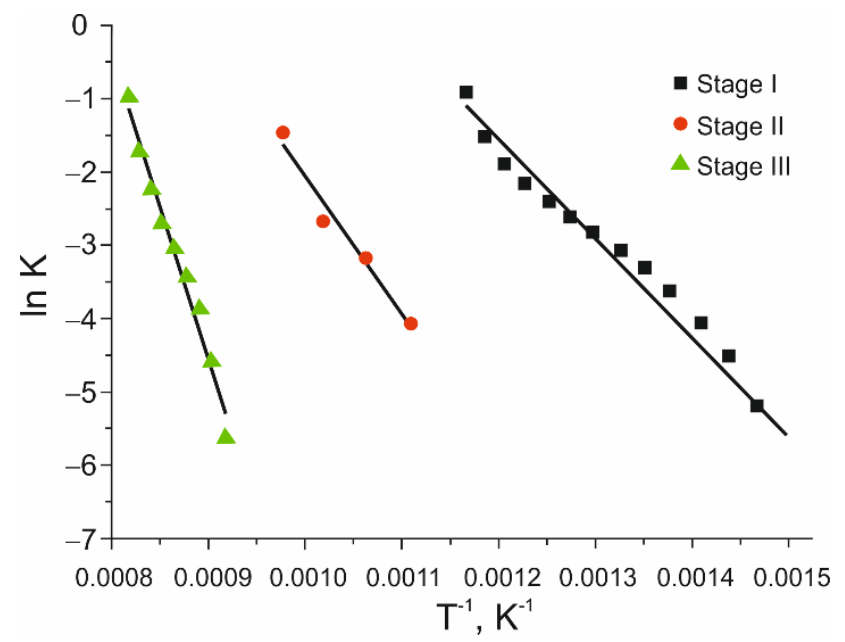

Figure 7. Arrhenius diagram of the pentlandite-bearing ore oxidation process.

Table 5. Calculated values of the activation energies.

\begin{tabular}{ccc}
\hline Temperature Range (K) & Stage & Ea (kJ Mol $\left.{ }^{-\mathbf{1}}\right)$ \\
\hline $667-856$ & I & 113 \\
$901-1023$ & II & 156 \\
$1089-1223$ & III & 346 \\
\hline
\end{tabular}

Calculated activation energies indicated that all three stages of the oxidation process occurred in a kinetic field [43]. These values were implying that in every examined stage of the oxidation process, temperature was a dominant parameter, determining the reaction rate. With the temperature increase, the values of Ea increased too, which meant that the oxidation process was even more "introduced" into the kinetic field. The temperature and the reaction surface had a more emphasized influence on the speed of the oxidation process. This also signified that a major part of the oxidation process took place on the surface boundary between the solid and gas phases.

\section{Conclusions}

The oxidation process of pentlandite-bearing ore was investigated in this paper. The characterization of the initial sample and the oxidation products was performed in a temperature range of $298-1073 \mathrm{~K}$, at different elevated temperatures. Additionally, thermodynamic, thermal and kinetic analyses results of the oxidation process were obtained. 
The results obtained via the XRD and SEM/EDS analyses were in a good mutual agreement, confirming that the initial sample consisted of pentlandite, pyrrhotite, chalcopyrite, pyrite, magnetite and gangue minerals (quartz and feldspar). The oxidation products hematite, magnetite and spinel phase trevorite were detected at elevated temperatures. $\mathrm{NiS}$ was observed up to $1073 \mathrm{~K}$.

The thermodynamic analysis of the investigated pentlandite-bearing sample involved the construction of Kellogg diagrams for the Ni-S-O and Fe-S-O systems. These diagrams were constructed at several temperatures: $298 \mathrm{~K}, 773 \mathrm{~K}, 923 \mathrm{~K}$ and $1073 \mathrm{~K}$. Based on the constructed diagrams, the theoretical reaction paths were suggested at $773 \mathrm{~K}, 923 \mathrm{~K}$ and $1073 \mathrm{~K}$ with defined partial pressures of $\mathrm{SO}_{2}$ and $\mathrm{O}_{2}$ gas, corresponding to industrial conditions. Thermodynamically possible reactions were proposed and values of change in Gibbs free energies were calculated at given temperatures.

The thermal analysis of the pentlandite-bearing ore oxidation process involved heating the initial sample in temperature range $298-1273 \mathrm{~K}$, in an air atmosphere, with a heating rate of $15^{\circ} \mathrm{min}^{-1}$. Obtained TG/DTA heating curves were analyzed and the results were compared to the XRD and SEM/EDS analyses and theoretical reaction paths, leading to proposing the actual reaction mechanism of the investigated oxidation process.

The kinetic analysis of the pentlandite-bearing ore oxidation process, was conducted by applying a non-isothermal kinetics calculation, according to the Daniels and Borchardt method. The kinetic analysis of the investigated oxidation process was based on the DTA heating curve with a constant heating rate of $15^{\circ} \mathrm{min}^{-1}$. Three different exothermal peaks were observed on the DTA heating curve, corresponding to three oxidation stages. Calculated activation energies were $113 \mathrm{~kJ} \mathrm{~mol}^{-1}, 146 \mathrm{~kJ} \mathrm{~mol}^{-1}$ and $356 \mathrm{~kJ} \mathrm{~mol}^{-1}$, respectively. These values implied that all three stages of the oxidation process occurred in a kinetic field, i.e., temperature was a dominant parameter, determining the reaction rate. A major part of the oxidation process took place on the surface boundary between the solid and gas phases.

The proposed reaction mechanism and kinetic analysis results presented in this paper could be considered for a better optimization of the oxidative roasting of nickel-bearing ores and concentrates in industrial conditions. Obtained results were in a good agreement with the available literature and represent a contribution to a better understanding of the complex sulfide ores oxidation process.

Author Contributions: N.Š., D.M. and M.S. designed and directed the project; D.M. provided the study materials; D.M., B.M., A.M., J.S. and K.B. performed the experiments and performed the analytic calculations; K.B. and A.M. prepared the original draft. All authors have read and agreed to the published version of the manuscript.

Funding: The research presented in this paper was conducted with the financial support of the Ministry of Education, Science and Technological Development of the Republic of Serbia, within the funding of the scientific research work at the University of Belgrade, Technical Faculty in Bor, according to the contract with registration number 451-03-9/2021-14/200131 and the Institute for Technology of Nuclear and Other Mineral Raw Materials, according to the contract with registration number 451-03-9/2021-14/200023.

Institutional Review Board Statement: Not applicable.

Informed Consent Statement: Not applicable.

Data Availability Statement: The data presented in this study are available on request from the corresponding author.

Acknowledgments: Authors would also like to express their gratitude to Vaso Manojlović from the Faculty of Technology and Metallurgy of the University of Belgrade, for his technical support and immerse help. The contribution of Gordana Mundrić, for proofreading the manuscript, is also greatly appreciated.

Conflicts of Interest: The authors declare no conflict of interest. 


\section{References}

1. Kuck, P.H. Nickel Mineral Commodity Summaries; United States Geological Survey: Washington, DC, USA, 2010; Available online: https://s3-us-west-2.amazonaws.com/prd-wret/assets/palladium/production/mineral-pubs/nickel/mcs-2010-nicke pdf (accessed on 12 February 2020).

2. Kuck, P.H. Nickel Mineral Commodity Summaries; United States Geological Survey: Washington, DC, USA, 2015; Available online: https://s3-us-west-2.amazonaws.com/prd-wret/assets/palladium/production/mineral-pubs/nickel/mcs-2015-nicke. pdf (accessed on 12 February 2020).

3. McRae, M.E. Nickel Mineral Commodity Summaries; United States Geological Survey: Washington, DC, USA, 2020. Available online: https:/ / pubs.usgs.gov/periodicals/mcs2020/mcs2020-nickel.pdf (accessed on 12 February 2020).

4. Betteridge, W. Nickel and Its Alloys; Ellis Horwood: Chichester, UK; Halsted Press: New York, NY, USA, 1984.

5. Vracar, R.Z. Theory and Practice of Extraction of Non-Ferrous Metals/Teorija i Praksa Dobijanja Obojenih Metala; Serbian Association of Metallurgy Engineers: Belgrade, Serbia, 2010.

6. Berndt, D. Maintenance-Free Batteries: Lead-Acid, Nickel/Cadmium, Nickel/Metal Hydride: A Handbook of Battery Technology, 2nd ed.; Research Studies Press: Baldock, UK, 1997.

7. Linden, D.; Reddy, T.B. Handbook of Batteries, 3rd ed.; McGraw-Hill: New York, NY, USA, 2002.

8. Gong, M.; Zhou, W.; Tsai, M.C.; Zhou, J.; Guan, M.; Lin, M.C.; Zhang, B.; Hu, Y.; Wang, D.Y.; Yang, J.; et al. Nanoscale nickel oxide/nickel heterostructures for active hydrogen evolution electrocatalysis. Nat. Commun. 2014, 5, 4695. [CrossRef]

9. Tasker, S.Z.; Standley, E.A.; Jamison, T.F. Recent advances in homogeneous nickel catalysis. Nature 2014, 509, 299-309. [CrossRef]

10. Konkena, B.; Junge Puring, K.; Sinev, I.; Piontek, S.; Khavryuchenko, O.; Dürholt, J.P.; Schmid, R.; Tüysüz, H.; Muhler, M.; Schuhmann, W.; et al. Pentlandite rocks as sustainable and stable efficient electrocatalysts for hydrogen generation. Nat. Commun. 2016, 7, 12269. [CrossRef]

11. Sokić, M.; Ilić, I.; Živković, D.; Vučković, N. Investigation of mechanism and kinetics of chalcopyrite concentrate oxidation process. Metalurgija 2008, 47, 109-113.

12. Mitovski, A.; Štrbac, N.; Mihajlović, I.; Sokić, M.; Stojanović, J. Thermodynamic and kinetic analysis of the polymetallic copper concentrate oxidation process. J. Therm. Anal. Calorim. 2014, 118, 1277-1285. [CrossRef]

13. Crundwell, F.K.; Moats, M.S.; Ramachandran, V.; Robinson, T.G.; Davenport, W.G. Extractive Metallurgy of Nickel, Cobalt and Platinum-Group Metal, 1st ed.; Elsevier: Amsterdam, The Netherlands, 2011.

14. Xia, F.; Pring, A.; Brugger, J. Understanding the mechanism and kinetics of pentlandite oxidation in extractive pyrometallurgy of nickel. Miner. Eng. 2012, 27-28, 11-19. [CrossRef]

15. Goryachev, A.A.; Chernousenko, E.V.; Potapov, S.S.; Tsvetov, N.S.; Makarov, D.V. A Study of the Feasibility of Using Ammonium Sulfate in Copper-Nickel Ore Processing. Metals 2021, 11, 422. [CrossRef]

16. Janjić, S.; Ristić, P. Mineralogy/Mineralogija; Scientific Book: Belgrade, Serbia, 1995.

17. Diaz, C.M.; Landolt, C.A.; Vahed, A.; Warner, A.E.M.; Taylor, W. A review of nickel pyrometallurgical operations. JOM 1988, 40, 28-33. [CrossRef]

18. Naldrett, A.J.; Craig, J.R.; Kullerud, G. The central portion of the Fe-Ni-S system and its bearing on pentlandite solution in iron-nickel sulfide ores. Econ. Geol. 1967, 62, 826-847. [CrossRef]

19. Mishra, K.C.; Fleet, M.E. The chemical composition of synthetic and natural pentlandite assemblages. Econ. Geol. 1973, 68, 518-539. [CrossRef]

20. Dunn, J.G. The oxidation of sulfide minerals. Thermochim. Acta 1997, 300, 127-139. [CrossRef]

21. Mkhonto, P.P.; Chauke, H.R.; Ngoepe, P.E. Ab initio studies of $\mathrm{O} 2$ adsorption on (110) Nickel-rich pentlandite $\left(\mathrm{Fe}_{4} \mathrm{Ni}_{5} \mathrm{~S}_{8}\right) \mathrm{mineral}$ surface. Minerals 2015, 5, 665-678. [CrossRef]

22. Thornhill, P.G.; Pidgeon, L.M. Micrographic study of sulfide roasting. JOM 1957, 9, 989-995. [CrossRef]

23. Ellingham, H.J.T. Reducibility of oxides and sulphides in metallurgical processes. J. Soc. Chem. Ind. 1944, 63, 125-133.

24. Ashcroft, E.A. Process for the Treatment of Ores or Materials Containing Copper and/or Nickel. U.S. Patent 1,851,885, 29 March 1932.

25. Tanabe, T.; Kawaguchi, K.; Asaki, Z.; Kondo, Y. Oxidation kinetics of dense pentlandite. Trans. JIM 1987, 28, 977-985. [CrossRef]

26. Kennedy, T.; Sturman, B.T. The oxidation of iron (II) sulphide. J. Therm. Anal. Calorim. 1975, 8, 329-337. [CrossRef]

27. Dunn, J.G.; Kelly, C.E. A TG/MS and DTA study of the oxidation of nickel sulphide. J. Therm. Anal. Calorim. 1977, 12, 43-52. [CrossRef]

28. Dunn, J.G.; Kelly, C.E. A TG/DTA/MS study of the oxidation of pentlandite. J. Therm. Anal. Calorim. 1980, 18, 147-154. [CrossRef]

29. Zhu, H.; Chen, J.; Deng, J.; Yu, R.; Xing, X. Oxidation behavior and mechanism of pentlandite at $973 \mathrm{~K}\left(700{ }^{\circ} \mathrm{C}\right)$ in air. Metall. Mater. Trans. B 2012, 43, 494-502. [CrossRef]

30. Dunn, J.G.; Jayweera, S.A. Effect of heating rate on the TG curve during the oxidation of nickel sulfide concentrates. Thermochim. Acta 1983, 61, 313-317. [CrossRef]

31. Pandher, R.; Utigard, T. Roasting of Nickel Concentrates. Metall. Mater. Trans. B 2010, 41, 780-789. [CrossRef]

32. Yu, D.; Utigard, T.A. TG/DTA study on the oxidation of nickel concentrate. Thermochim. Acta 2012, 533, 56-65. [CrossRef]

33. Hseu, Z.Y. Evaluating heavy metal contents in nine composts using four digestion methods. Bioresour. Technol. 2004, 95, 53-59. [CrossRef] [PubMed] 
34. Shultz, J.I.; Bell, R.K.; Rains, T.C.; Menis, O. Methods of Analysis of NBS Clay Standards; National Bureau of Standards Special Publication 260-37; National Bureau of Standards: Washington, DC, USA, 1972; pp. 3-4.

35. Borchard, H.J.; Daniels, F. The Application of Differential Thermal Analysis to the Study of Reaction Kinetics. J. Am. Chem. Soc. 1957, 79, 41-46. [CrossRef]

36. Živković, D.; Živković, Ž. Problems in the Theory of Metallurgical Processes/Zbirka Zadataka iz Teorije Metlurških Procesa; University of Belgrade, Technical Faculty in Bor: Belgrade, Serbia, 2001.

37. Roine, A. HSC Chemistry ${ }^{\circledR}$ v 9.0; Research Oy Center, Outotec: Pori, Finland, 2016.

38. Shamsuddin, M. Roasting of Sulfide Minerals. In Physical Chemistry of Metallurgical Processes; John Wiley \& Sons: Hoboken, NJ, USA, 2016; pp. 39-71.

39. Zhang, Y.; Li, Q.; Liu, X.; Xu, B.; Yang, Y.; Jiang, T. A Thermodynamic Analysis on the Roasting of Pyrite. Minerals 2019, 9, 220. [CrossRef]

40. Smirnov, V.I.; Tihonov, A.I. Incineration of Copper Ores and Concentrates/Obţig Mednih Rud i Koncentratov; Metallurgy: Moscow, Russia, 1966.

41. Mayangsari, W.; Prasetyo, A.B. Phase Transformation of Limonite Nickel Ores with $\mathrm{Na}_{2} \mathrm{SO}_{4}$ Addition in Selective Reduction Process. IOP Conf. Ser. Mater. Sci. Eng. 2017, 202, 012016. [CrossRef]

42. Dunn, J.G.; Howes, V.L. The oxidation of violarite. Thermochim. Acta 1996, 282-283, 305-316. [CrossRef]

43. Živković, Ž. Theory of Metallurgical Processes/Teorija Mealurških Proces; University of Belgrade, Technical Faculty in Bor: Belgrade, Serbia, 1991. 